\title{
Xenograft models for pediatric cancer therapies
}

\author{
Kevin O. McNerney (iD) ${ }^{1}$ David T. Teachey (iD) ${ }^{1,2^{*}}$ \\ ${ }^{1}$ Children's Hospital of Philadelphia, Divisions of Hematology and Oncology, Philadelphia, PA 19104, USA \\ ${ }^{2}$ Perelman School of Medicine, University of Pennsylvania, Philadelphia, PA 19104, USA
}

\begin{abstract}
The prognosis for childhood cancer has improved considerably over the past 50 years. This improvement is attributed to welldesigned clinical trials which have incorporated chemotherapy, surgery, and radiation. With an increased understanding of cancer biology and genetics, we have entered an era of precision medicine and immunotherapy that provides potential for improved cure rates. However, preclinical evaluation of these therapies is more nuanced, requiring more robust animal models. Evaluation of targeted treatments requires molecularly defined xenograft models that can capture the diversity within pediatric cancer. The development of novel immunotherapies ideally involves the use of animal models that can accurately recapitulate the human immune response. In this review, we provide an overview of xenograft models for childhood cancers, review successful examples of novel therapies translated from xenograft models to the clinic, and describe the modern tools of xenograft biobanks and humanized xenograft models for the study of immunotherapies.
\end{abstract}

\section{Keywords}

Xenograft, pediatric cancer, preclinical model, immunotherapy, precision medicine

\section{Peer Review}

The peer reviewers who approve this article are:

1. Esther Hulleman, Princess Máxima Center for Pediatric Oncology, Utrecht, The Netherlands Competing interests: No competing interests were disclosed.

2. Mario Otto, Division of Hematology, Oncology \& Bone Marrow Transplant, Department of Pediatrics, University of Wisconsin School of Medicine and Public Health, Madison, Wisconsin, USA

Competing interests: No competing interests were disclosed. 
*Corresponding author: David T. Teachey (teacheyd@chop.edu)

Competing interests: The authors declare that they have no competing interests.

Grant information: David Teachey was supported by funds from the National Institutes of Health (NIH) grant RO1 CA193776/CA/NCI NIH

HHS/United States. Kevin McNerney was supported by the National Center for Advancing Translational Sciences of the NIH under award number

TL1TR001880. The content is solely the responsibility of the authors and does not necessarily represent the official views of the National Institutes of Health.

The funders had no role in study design, data collection and analysis, decision to publish, or preparation of the manuscript.

Copyright: (c) 2021 Teachey DT et al. This is an open access article distributed under the terms of the Creative Commons Attribution License, which permits unrestricted use, distribution, and reproductison in any medium, provided the original work is properly cited.

How to cite this article: McNerney KO and Teachey DT. Xenograft models for pediatric cancer therapies. Faculty Reviews 2021 10:(11) https:// doi.org/10.12703/r/10-11

Published: 02 Feb 2021, Faculty Reviews 10:(11) https://doi.org/10.12703/r/10-11 


\section{Introduction}

The prognosis for childhood cancer has improved considerably over the past 50 years. In children, 5-year overall survival (OS) has increased from $58 \%$ in $1975-1977$ to $84 \%$ in $2009-2015$; for adults, the increase was from 49 to $69 \%$. Improvements in survival have occurred in most, but not all, types of pediatric cancers. The 5-year OS of childhood acute lymphoblastic leukemia (ALL), for example, has increased from 27 to $91 \%$, and significant improvements have also been seen in retinoblastoma, soft tissue sarcomas, hepatic and germ cell tumors, Wilms tumor (WT), and neuroblastoma ${ }^{1,2}$. These gains can be attributed to well-designed clinical trials that have integrated chemotherapy, radiation, and surgery, as well as improved standard of care, including supportive care. Unfortunately, the prognosis for children with relapsed disease remains poor for most pediatric cancers. For other tumors, including diffuse intrinsic pontine glioma (DIPG) and metastatic solid tumors, survival remains dismal, even in newly diagnosed patients. Additionally, improvements in survival have come with the cost of late effects; approximately $67 \%$ of childhood cancer survivors develop at least one chronic health condition ${ }^{3}$.

With the use of histology and immunohistochemistry, pediatric malignancies can be grouped into a relatively small number of subtypes. Early clinical trials were designed based on histopathologic diagnoses. As molecular biology and genetics have advanced, knowledge of the diverse genetic, epigenetic, and proteomic landscape of cancer has ushered in the era of precision medicine and targeted therapies. Additionally, insights in immunobiology and clinical successes of immune-based treatments of select cancers have re-invigorated the field of cancer immunotherapy. The abundance of molecularly targeted and immune therapies in development provide a new horizon for some cancers. However, children are not little adults, and pediatric cancers are biologically distinct from adult cancers. Thus, before new therapies can be moved into the clinic, robust preclinical testing in appropriate models of childhood cancer is needed.

Historically, cell lines and transgenic mice were adequate for the testing of new agents in histopathologically defined disease. While both still have important utility, in an era of precision medicine and immunotherapy, more robust models are needed. Transgenic mouse and cell lines will always remain integral to the study of new agents and disease biology, but models that can reflect the enormous molecular diversity of human cancer are vital.

It is beyond the scope of this review to discuss all the different types of preclinical models for pediatric cancer. Instead, we will provide an overview of the history of xenograft models of childhood cancers, review successful examples of the translation of novel therapies from xenograft models to the clinic, and describe ongoing efforts to establish comprehensive xenograft biobanks and humanized xenograft models for the study of immunotherapies.
Patient-derived xenografts, molecular characterization, and implications for pediatric cancer treatments

Xenografts involve transplantation of human tumor tissue or cell lines into animals that have been modified to accept the graft $^{4-7}$. Traditional patient-derived xenograft (PDX) models are generated by implantation or injection of human malignant cells into the flank, peritoneum, or tail vein of mice made to be immunodeficient, as mice with intact immune systems will reject the foreign tumor tissue. The human cells may be from fresh tumor samples or from primary cell lines passaged in vitro in growth media in monolayer cultures. However, xenografts from established cancer cell lines allow for a limited investigation of different biologies which are often changed by immortalization $^{8,9}$. PDX models were first created with athymic nude mice, then severe combined immunodeficiency (SCID) mice, followed by more immunodeficient models (Table 1$)^{10-14}$. Patient-derived orthotopic xenografts (PDOXs) are generated by transplanting tumor tissue from a patient (often including stroma, fibroblasts, and co-opted immune cells) into a mouse in the same anatomic location as the parent tumor. This strategy preserves the structure of a tumor and helps to more closely recapitulate the tumor microenvironment (TME) ${ }^{6,15}$.

It is important to note that while these models recapitulate pediatric tumors allowing for much-needed investigations, they have limitations. Namely, in order to accept the xenografts, recipient murine immune systems must be abnormal. Furthermore, human tumor biology in living mouse models is altered by the presence of murine cellular and extracellular contaminants. Finally, there is the potential for clonal evolution of the xenograft resulting in a tumor that is different genotypically and phenotypically from the parent tumor tissue. To counteract the latter limitations, these models are validated by comparing the histologic and genetic features of the PDX or PDOX tumor to primary tumor samples. Genomic methods such as whole exome/genome sequencing and transcriptome profiling are used to confirm sentinel genetic alterations that are retained ${ }^{16,17}$. An unfortunate difficulty in xenograft-based research can be access to models. Privately developed xenograft models and xenograft model systems generated by individual institutions may not be as widely accessible. Expanding access to models is an important need for the scientific community.

Both PDX and PDOX models require immunocompromised mice. Conversely, syngeneic mouse models are immunocompetent but are engrafted with tumor lines from the same genetic background to avoid immune rejection. The murine origin of the tumor line limits the applicability of the model to human disease but can be useful in studying the influence of the immune system. Transgenic mice, also known as genetically engineered mouse models (GEMMs), offer another immunocompetent option. These models are generated via the insertion of oncogenes, or knockout of tumor suppressor genes, in murine systems $^{18,19}$. The transgenes can be expressed constitutively or conditionally, leading to endogenous tumor development. 
Table 1. Common xenograft mouse models used in pediatric cancer research.

\begin{tabular}{|c|c|c|c|c|}
\hline Mouse strain & Genetic variant & $\begin{array}{l}\text { Mature B } \\
\text { cells }\end{array}$ & $\begin{array}{l}\text { Mature T } \\
\text { cells }\end{array}$ & $\begin{array}{l}\text { Innate immunity/ } \\
\text { NK-cells }\end{array}$ \\
\hline BALB/c nu/nu (Athymic Nude) & Foxn1 & + & - & ++ \\
\hline SCID & Prkdc scid & (leaky) & (leaky) & ++ \\
\hline NOD/SCID & HLA haplotype $\mathrm{H}^{\mathrm{G}}{ }^{\mathrm{G}} /$ Prkdc ${ }^{\text {scid }}$ & - & - & + \\
\hline RAG1/2null & Rag $1^{\text {null }}$ and/or Rag $2^{\text {null }}$ & - & - & + \\
\hline BALB/c/RAG2 ${ }^{\text {null }} \gamma_{c}^{\text {null }}(D K O)$ & 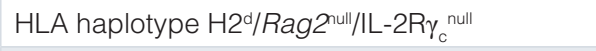 & - & - & - \\
\hline NOD/SCID/Gamma (NSG) & HLA haplotype $\mathrm{H} 2^{\mathrm{G} 7} /$ Prkd $c^{\text {scid }} / / 2 \mathrm{rg}^{\mathrm{tm} T W_{\mathrm{I}} / \mathrm{SzJ}}$ & - & - & - \\
\hline $\mathrm{NOD} / \mathrm{SCID} / \gamma_{\mathrm{c}}^{\text {null }}(\mathrm{NOG})$ & $\begin{array}{l}\text { HLA haplotype } \mathrm{H}^{\mathrm{G} 7} / \mathrm{Prkd}^{\text {scid }} \\
\text { /II2rg } \\
\text { tm/Sug/JicTac }\end{array}$ & - & - & - \\
\hline $\mathrm{NOD} / \mathrm{SCID} / \beta 2 \mathrm{~m}^{\text {null }}$ & HLA haplotype $\mathrm{H}^{\mathrm{G} 7} /$ Prkd $c^{\text {scid }} / \beta 2 \mathrm{~m}^{\text {null }}$ & - & - & - \\
\hline NSG/ß2m null & 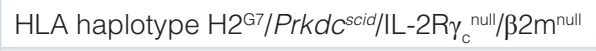 & - & - & - \\
\hline $\begin{array}{l}\text { NOD/SCID/SGM3 } \\
\text { (N/S-SGM3) }\end{array}$ & $\begin{array}{l}\text { HLA haplotype H2G7/Prkdc scid/hSCF/hGM- } \\
\text { CSF/hIL-3 }\end{array}$ & - & - & + \\
\hline Humanized NSG & HLA haplotype $\mathrm{H} 2^{\mathrm{G} 7} / \operatorname{Pr} k d c^{\text {scid } / I L-2 R} \gamma_{c}^{\text {null* }}$ & + (human) & + (human) & $\begin{array}{l}+/- \\
\text { (human) }\end{array}$ \\
\hline $\begin{array}{l}\text { Humanized SGM3 } \\
\text { (NSG-SGM3 or NSGS) }\end{array}$ & $\begin{array}{l}\text { HLA haplotype } \mathrm{H}^{\mathrm{G} 7} / \text { Prkd } c^{\text {scid } / I L-2 R} \gamma^{\text {null }} / \mathrm{hSCF} / \\
\text { hGM-CSF/hIL-3 }\end{array}$ & $\stackrel{+}{\text { (human) }}$ & $\stackrel{+}{\text { (human) }}$ & $\stackrel{+}{\text { (human) }}$ \\
\hline Humanized MI(S)TRG & 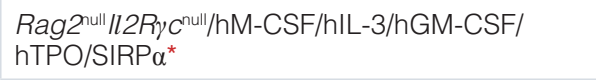 & $\stackrel{+}{\text { (human) }}$ & $\begin{array}{l}+ \\
\text { (human) }\end{array}$ & $\stackrel{+}{\text { (human) }}$ \\
\hline
\end{tabular}

Abbreviations: -, deficient; +, present; ++, robust expression; $\beta 2 \mathrm{~m}^{\text {null, }}$, major histocompatibility class I beta-2-microglobulinull; hGM-CSF, human granulocyte-macrophage-colony stimulating factor; hIL-3, human interleukin-3; hM-CSF, human myeloid-colony stimulating factor; HSC,

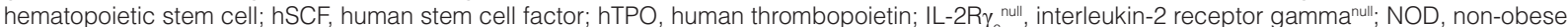
diabetic; NSG, NOD/SCID/IL-2R $\gamma^{\text {null; }}$ SCID, severe combined immunodeficiency; SGM3, NSG hSCF, hGM-CSF, hIL-3 triple transgenic mice; SIRPa, signal regulatory protein $\alpha$; RAG, recombination-activating gene.

*xenografted with human HSCs

Transgenic mice offer the potential of studying genetically defined malignancies in immunocompetent mice, albeit with malignant cells of murine origin.

The advent of "humanized" mice allows examination of the interplay between the human immune system and malignant cells in mouse models. In these models, immunocompromised mice are irradiated, then engrafted with human hematopoietic stem cells derived from human blood, bone marrow, cord blood (CB), fetal liver, and, in some models, fetal thymus for T-cell maturation ${ }^{20}$. These mice can then be xenografted with genetically similar human tumors that will not be rejected. Various modifications to these models have been made to promote human immune system development and prevent xenograft versus host disease (xGVHD), as we will discuss below.

In addition to in vivo modeling, recent advances such as the use of three-dimensional (3D) tumor culture systems including tumor explants, tumor-on-a-chip technology, and multicellular tumor spheroids have allowed for in vitro study of cancers that more closely approximate the TME. These models can contain numerous cell types including fibroblasts, endothelial cells, and mesenchymal stem cells as well as extracellular matrix and cytokines similar to native human tumors. Additionally, 3D tumor models such as multicellular tumor spheroids have gene expression profiles, gradients of nutrients and oxygen, and biological zones that are more similar to in vivo tumors than cells in monolayer cultures, making these valuable options for pediatric cancer modeling ${ }^{21}$.

\section{Xenograft models in acute lymphoblastic leukemia}

One of the earliest successful examples of PDX development is the engraftment of lymphoblasts from patients with ALL into SCID mice. SCID mice lack mature B- or T-cells and are capable of accepting ALL blasts at a rate of $\sim 15 \%{ }^{22-25}$. Interestingly, the low engraftment rates had prognostic utility in one study, as blasts from patients with higher risk, poorer prognosis ALL were more likely to engraft ${ }^{24}$. As only ALL blasts from high-risk disease engrafted in SCID mice, only a genetically narrow population was studied using early models. In order to study a more comprehensive subset of patient-derived ALL, more immunodeficient mouse models were required. The backcrossing of SCID mice with non-obese diabetic (NOD) mice led to a more completely immunodeficient NOD/SCID mouse, which accepts ALL patient samples at rates of $\sim 75 \%{ }^{26-28}$. Although, in NOD/SCID mice, persistent natural killer (NK)-cells continue to mediate leukemia rejection. On the NOD/SCID background, interleukin-2 receptor gamma chain $(I L 2 R \gamma)$ was modified to further impair the innate immunity of these animals ${ }^{29}$. The resultant NOD/SCID/gamma (NSG) mice have no mature B-cell, 
T-cell, or NK-cell immunity to mediate rejection and therefore have higher rates of ALL engraftment ${ }^{29}$. Knockout of the major histocompatibility complex class I beta2-microglobulin $(\beta 2 m)$ in NSG mice allows engraftment of $>90 \%$ of ALL patient samples $^{30}$.

Pediatric ALL xenografts have been used extensively to study disease biology by expanding the number of blasts for mechanistic evaluation. A few hundred thousand blasts injected into a mouse can expand to billions of blasts for ex vivo analysis. ALL xenografts have also been used to test novel therapies (Table 2). Blinatumomab, a bi-specific T-cell engager (BiTE) for CD19 and CD3, was investigated in NOD/SCID mice supplemented with human T-cells, providing efficacy and safety data for clinical trials ${ }^{31-34}$. Other agents broadly tested in ALL models that have led to clinical trials include immunotherapies such as chimeric antigen receptor (CAR) T-cells and monoclonal antibodies targeting CD19 and CD22 (discussed below), small

Table 2. Examples of experimental therapies used in pediatric cancer xenograft models.

\begin{tabular}{|c|c|c|c|}
\hline Pediatric cancer & $\begin{array}{l}\text { FDA-approved agent } \\
\text { tested }\end{array}$ & $\begin{array}{l}\text { Investigational agent } \\
\text { tested }\end{array}$ & Mouse strain \\
\hline ALL & $\begin{array}{l}\text { Venetoclax }{ }^{35-37} \\
\text { CAR T-cells } \\
\text { I8-43 } \\
\text { Imatinib }^{44} \\
\text { Blinatumomab }^{34,45}\end{array}$ & $\begin{array}{l}\text { Denintuzumab }{ }^{46} \\
\text { Palbociclib }^{47} \\
\gamma \text {-secretase inhibitor } \\
\text { Ruxolitonib } \\
\text { Trametinib }^{50} \\
\text { Ml-3454 }^{51} \\
\text { Navitoclax }^{52}\end{array}$ & $\begin{array}{l}\mathrm{NSG}^{49-52} \\
\mathrm{C}^{4 H} 2^{38} \\
\text { MI(S)TRG } \\
\text { B6.SJL CD } 45.1+ \\
\text { Ccnd2 }{ }^{-1-} \text { and } \\
\text { Ccnd3 }^{-1-47} \\
\text { NOD/SCID } \\
49,52\end{array}$ \\
\hline AML & $\begin{array}{l}\text { Venetoclax }{ }^{35-37} \\
\text { Gemtuzumab }^{54}\end{array}$ & $\begin{array}{l}\text { Cobimetinib }^{55} \\
\text { MI-3454 } \\
\text { Quizartinib } \\
\text { VTP5046957 }\end{array}$ & $\begin{array}{l}\text { NSGS }^{55} \\
\text { NOD/SCID }^{56} \\
\text { NSG }^{35,51,57}\end{array}$ \\
\hline $\mathrm{CML}$ & $\begin{array}{l}\text { Dasatinib }^{58,59} \\
\text { Nilotinib }^{60} \\
\text { Imatinib }^{44}\end{array}$ & $\begin{array}{l}\text { GSK34358 } \\
\text { Hydroxychloroquine }{ }^{61}\end{array}$ & $\begin{array}{l}\mathrm{DBA} / 2 \mathrm{~J}^{60} \\
\mathrm{NSG}^{58,61}\end{array}$ \\
\hline Hodgkin lymphoma & $\begin{array}{l}\text { Brentuximab }{ }^{62-64} \\
\text { Nivolumab }^{65,66}\end{array}$ & $\begin{array}{l}\text { Ruxolitinib } 67,68 \\
\text { Navitoclax }^{64}\end{array}$ & $\begin{array}{l}\text { NOD/SCID } \\
\text { NSG }^{67,68}\end{array}$ \\
\hline $\mathrm{NHL}$ & $\begin{array}{l}\text { Rituximab }{ }^{69} \\
\text { CAR T-cells (DLBCL) }\end{array}$ & $\begin{array}{l}\text { Obinotuzumab }^{70} \\
\text { Ofatumumab } \\
\text { Fedratinib } \\
\text { Ruxolitonib } \\
\text { Midostaurin }^{71,72}\end{array}$ & $\begin{array}{l}\operatorname{SCID}^{67,68,70,71} \\
\text { NSG }^{72}\end{array}$ \\
\hline Neuroblastoma & Dinutuximab ${ }^{73}$ & $\begin{array}{l}\text { Galunisertib }^{74} \\
\text { CAR T-cells }^{75} \\
\text { CAR NKT-cells }^{76} \\
\text { Crizotinib }^{2,77-79 *} \\
\text { Ceritinib }^{77} \\
\text { CGM097 }^{78,80} \\
\text { Lorlatinib }^{81}\end{array}$ & $\begin{array}{l}\mathrm{SCID}^{77,78} \\
\mathrm{NSG}^{74,82} \\
\mathrm{Hu}-\mathrm{NSG}^{76} \\
\mathrm{BALB} / \mathrm{C}-\mathrm{Nu}^{78,81}\end{array}$ \\
\hline Wilms tumor & & $\begin{array}{l}\text { Lorvotuzumab- } \\
\text { mertansine } \\
\text { WT1-directed } \\
\text { vaccine }^{84} \\
\text { AZD1775 }\end{array}$ & $\begin{array}{l}\text { NOD/SCID } \\
\text { BALB/, } / \mathrm{c}^{84}\end{array}$ \\
\hline Rhabdomyosarcoma & & $\begin{array}{l}\text { Panobinostat, } \\
\text { bortezomib, } \\
\text { AZD1775 }\end{array}$ & $\begin{array}{l}\text { NOD/SCID } \\
\text { NSG }^{86}\end{array}$ \\
\hline
\end{tabular}




\begin{tabular}{|c|c|c|c|}
\hline Pediatric cancer & $\begin{array}{l}\text { FDA-approved agent } \\
\text { tested }\end{array}$ & $\begin{array}{l}\text { Investigational agent } \\
\text { tested }\end{array}$ & Mouse strain \\
\hline Ewing sarcoma & & $\begin{array}{l}\text { Mithramycin }{ }^{87} \\
\text { Trabectidin }^{88}\end{array}$ & $\begin{array}{l}\mathrm{SCID}^{87} \\
\mathrm{Crl}-\mathrm{Nu} / \mathrm{Fox} 1-\mathrm{Nu}^{88}\end{array}$ \\
\hline Osteosarcoma & & ML264 $4^{89}$ & BALB/C-Nu ${ }^{89}$ \\
\hline Medulloblastoma & & Vismodegib $19,90,91$ & $\begin{array}{l}\text { Ptch1 }^{+/-} \text {\& } \\
\text { Tp53 }^{-/-91} \\
\text { NSG }^{90}\end{array}$ \\
\hline Glioblastoma & & $\begin{array}{l}\text { Erlotinib }^{90} \\
\text { Veliparib }^{92}\end{array}$ & $\begin{array}{l}\mathrm{NSG}^{90} \\
\mathrm{SCID} \& \mathrm{BALB} / \mathrm{C} \\
\mathrm{Nu}^{92}\end{array}$ \\
\hline
\end{tabular}

Abbreviations: ALL, acute lymphoblastic leukemia; AML, acute myeloid leukemia; $\mathrm{C} 3 \mathrm{H}, \mathrm{C} 3 \mathrm{H} / \mathrm{HeN}-\mathrm{MTV}$ negative; CML, chronic myeloid leukemia; DLBCL, diffuse large B cell lymphoma; hu-NSG, humanized NSG; NKT, natural killer T; NHL, non-Hodgkin lymphoma; NOD, non-obese diabetic; NSG, NOD/SCID/IL-2R $\gamma^{\text {null; }}$ SCID, severe combined immunodeficiency.

*FDA approved in non-small cell lung cancer

molecule inhibitors targeting NOTCH, CDK4/6, PI3K/Akt/mTOR, JAK/STAT, and mitogen-activated protein kinase (MAPK), and cytotoxic chemotherapeutics ${ }^{32,45,47-49,93,94}$. ALL xenograft models have been used to compare the differential sensitivity of drugs in diagnostic:relapse pairs generated from individual patients to study clonal evolution ${ }^{50}$. Finally, ALL xenografts have been used to study targeted therapies in high-risk ALL subtypes, including BCL2 inhibitors in hypodiploid ALL, JAK/STAT inhibitors in early T-cell precursor (ETP) ALL, and ABL-kinase inhibitors in $\mathrm{Ph}$-like $\mathrm{ALL}^{49,95,96}$.

\section{Xenograft models in acute myeloid leukemia}

In contrast to ALL, acute myeloid leukemia (AML) xenografts have been more difficult to establish in NOD/SCID and NSG mice because of low levels of engraftment and poor proliferation of malignant cells ${ }^{97-99}$. Other model systems have more robust engraftment, including NOD/SCID/ $\beta 2 \mathrm{~m}^{\text {null }}$ mice and NOD/SCID mice with transgenic expression of stem cell factor (SCF), granulocyte/macrophage-colony stimulating factor (GM-CSF), and interleukin-3 (IL-3) (N/S-SGM3 mice), which facilitate AML engraftment and proliferation ${ }^{100}$. AML PDX models have been used to investigate small molecule inhibitors such as the BCL-2 inhibitor venetoclax, which led to clinical trials in adults and children and eventual FDA approval in adults $>75$ years

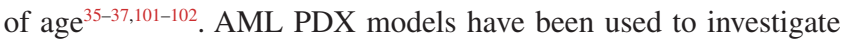
combination therapies such as venetoclax with the MAPK inhibitor cobimetinib in NSG mice modified with SGM3 transgenes (NSGS mice) $)^{55}$. This work has also led to clinical trials. Similar to ALL models, AML PDX models have been used to study targeted therapies, including FLT3 inhibitors in FLT3/ITD AML PDX models and menin inhibitors in KMT2A-rearrangement (KMT2A-r) AML ${ }^{51,56,57}$. Immunotherapies have also been used in AML PDX models (discussed below).

\section{Xenograft models in chronic myeloid leukemia}

Chronic myeloid leukemia (CML) is a proliferative disorder involving the accumulation of early myeloid precursors as a result of the formation of the $B C R-A B L 1$ fusion protein formed by reciprocal translocation of chromosomes 9 and $22^{103}$. CML can have three phases as blasts acquire additional genetic alterations: chronic phase, accelerated phase, and blast crisis. In early CML xenograft experiments that used SCID mice, only PDXs from patients in blast crisis could reliably engraft ${ }^{104}$. Later, irradiated SCID mice and NOD/SCID mice accepted PDXs from patients in chronic phase as well as blast crisis ${ }^{105,106}$. Another study found that CML patient samples with a high percentage of long-term culture-initiating cells (LT-CICs) were most capable of consistent long-term engraftment in irradiated NOD/SCID and NOD/SCID/ $/ 32 \mathrm{~m}^{\text {null }}$ mice ${ }^{107}$. Human $\mathrm{CB} C D 34^{+}$cells have been transduced for $B C R-A B L 1$ expression with resultant leukemia initiation in NOD/SCID mice. Engraftment was further improved when $B C R-A B L 1$-expressing human cells were made to co-express BMI1, suggesting that BMI1 may be a valuable target in CML therapy ${ }^{108}$.

One of the main hurdles in CML therapy is tyrosine kinase inhibitor (TKI) resistance. NSG xenograft models using TKI-resistant CML lines and PDXs have been used to explore mechanisms of TKI resistance ${ }^{58,60,61}$. In these studies, autophagy was found to contribute to TKI resistance, and blockade of autophagosome formation with hydroxychloroquine was shown to have synergistic action with mTOR inhibitors, prompting interest in mTOR inhibitor/autophagosome inhibitor combination therapy for patients with TKI resistance ${ }^{61}$. Albeit, similar results were not found in the clinic ${ }^{44}$. CML PDX models have been used to test numerous second- and third-generation TKIs as well as combination therapies such as EZH2 inhibitors in combination with TKIs ${ }^{58,109,110}$.

\section{Xenograft models in Hodgkin lymphoma}

Hodgkin lymphoma (HL) xenografts were initially challenging to generate owing to the relative scarcity and poor growth of Hodgkin and Reed-Sternberg (HRS) cells, the malignant cells in HL. At least one group successfully generated primary 
xenografts from primary HL tissue in SCID mice, but only with engraftment from $3 / 13$ patients $(23 \%)$, and with high rates of Epstein-Barr positivity in non-HRS cells (80-100\%). Furthermore, the tumors generated from these engraftments had three different morphologic patterns: lymphoproliferative disease, anaplastic large cell lymphoma (ALCL), and Hodgkin-like ${ }^{111}$. In SCID mice, xenografts from HL cell lines generated tumors at a rate of $57 \%^{112,113}$. Because of the difficulty of primary tumor engraftment, it is now more common for HL xenograft experiments to utilize cell lines instead of primary patient samples. HL cell line xenograft models in SCID mice have been used to test novel therapies, including monoclonal antibodies targeting $\mathrm{CD} 30$, such as $\mathrm{AC} 10$ and $5 \mathrm{~F} 11^{114-116}$. 5F11, however, was not effective in clinical trials ${ }^{117}$. In contrast, cell line HL xenograft models also were used to test the efficacy of brentuximab, which was derived from cAC10 conjugated to monomethyl auristatin $\mathrm{E}$ via a valine-citrulline peptide linker ${ }^{118}$. Brentuximab demonstrated both preclinical and clinical efficacy and is now FDA approved $62,63,119$.

\section{Xenograft models in non-Hodgkin lymphoma}

Non-Hodgkin lymphoma (NHL) mouse models have also been generated and provided valuable preclinical data that have led to progress in the clinical domain. For example, cells from patient-derived ALCL tumors were injected into the flanks of NOD.cg-Prkdc $c^{\text {scid }}$ IL2 rg $^{\text {tmlsug }}$ (NOG) mice with successful engraftment and lymphoma dissemination ${ }^{120}$. Brentuximab, mentioned above, also had demonstrated efficacy preclinically in ALCL xenografts into SCID mice, leading to translation with efficacy in patients ${ }^{62,118}$. Primary mediastinal large B cell lymphoma (PMBL) is a subtype of diffuse large B-cell lymphoma (DLBCL) that occurs predominantly in young adults ${ }^{67}$. PMBL xenograft models have not been generated with primary tumor samples but have been generated using Karpas1106P and MedB1 cell lines, allowing treatment responsiveness assessment with targeted JAK2 inhibition with fedratinib and ruxolitinib as well as with the anti-79b antibody-drug conjugate polatuzumab vedotin ${ }^{67,68,121}$. Interestingly, PMBL cell lines were shown to have sensitivity to ruxolitinib in both in vitro and Karpas1106P-xenografted NSG mice, although this did not translate to therapeutic responses in a small phase 2 trial $^{67,68}$. A phase 1 clinical trial evaluating polatuzumab in patients with PMBL is now recruiting (NCT04231877).

Burkitt lymphoma (BL), a NHL representing 40-50\% of all pediatric lymphomas, was first studied in transgenic mouse models (MYC gene under the control of $\operatorname{IgH}$ or $\operatorname{IgL}$ sequence $)^{122-124}$. Subsequently, PDX BL models were generated from affected patient lymph nodes in athymic nude and SCID mice, demonstrating metastatic potential in SCID mice, but not in athymic nude mice ${ }^{125}$. These models have been used to study novel agents such as the pan-protein kinase $\mathrm{C}$ (PKC) inhibitor midostaurin with and without rituximab ${ }^{71,126}$. Promising results in preclinical models have led to ongoing clinical trials ${ }^{71}$.

\section{Xenografts in neuroblastoma}

Solid tumor xenograft models have proven useful for the study and development of effective treatment regimens in pediatric cancers. In neuroblastoma, orthotopic and systemic xenograft models were developed in BALB/c/Rag $2^{\text {null }} \gamma_{c}{ }^{\text {null }}$ mice with adrenal or intravenous injection of human IMR-32 and IGR-N91 neuroblastoma cell lines ${ }^{127}$. In NSG mice, patient-derived primary neuroblastoma samples that were cryopreserved after surgery were used to create PDOX models that demonstrated invasive growth patterns and retention of patient-specific genetic markers, as well as the ability for the tumors to be monitored with PET and MRI imaging ${ }^{128}$. These models were used to test dinutuximab (Unituxin ${ }^{\mathrm{TM}}$ ), an IgG1 human/mouse chimeric switch variant of $14 \mathrm{G} 2 \mathrm{a}$, targeting GD2 on neuroblasts ${ }^{73,129,130}$. Promising preclinical results led to clinical trials and eventual FDA approval of dinutuximab in children with high-risk neuroblastoma with at least partial response to first-line multi-agent, multi-modal therapy ${ }^{73}$. More recent preclinical studies have tried to improve the efficacy of dinutuximab by enhancing the immune response. These have included the study of the TGF- $\beta$ inhibitor galunisertib as well as the use of activated NK-cell infusion with dinutuximab in neuroblastoma-xenografted NSG mice; both of the combinations were superior to monotherapy ${ }^{74,131}$.

Neuroblastoma xenografts have also been used to test targeted therapies. As an example, neuroblastoma cell lines with ALK variants or ALK amplification in athymic nude and SCID mice have been used to study ALK inhibitors alone, and in combination with chemotherapy, demonstrating improved tumor control and prolonged survival in these models $77,99,132,133$.

\section{Xenografts in Wilms tumor}

Initial attempts to make PDXs from WT had engraftment rates of approximately $30 \%$, and cell lines made from WT samples would not engraft ${ }^{134}$. Then, using $1 \times 3 \times 3 \mathrm{~mm}^{3}$ minced WT fragments implanted underneath the renal capsules of athymic nude mice, one group demonstrated a $67 \%$ engraftment rate $^{135}$. When another group xenografted minced WT tumors in NOD/SCID mice, engraftment rates of $80 \%$ were found ${ }^{83}$. This was attributed to the proportion of the WT sample that included the blastemal component, which was found to have a distinct gene expression pattern and was thought to confer stem-like properties to the xenografts ${ }^{83}$. Finally, another group generated a WT PDX library, successfully xenografting 45 WT patient samples into SCID mice. These PDXs demonstrated consistent enrichment of the blastema relative to primary tumors ${ }^{136}$. This PDX library was treated with doxorubicin, actinomycin D, and vincristine, demonstrating sensitivity in xenografts derived from favorable histology WT, and more frequent refractoriness in PDXs from anaplastic WT samples ${ }^{136}$. WT models have also been used to test novel therapies, including a human NCAM antibody-drug conjugate called lorvotuzumab-mertansine. WT tumors were completely eradicated in the mice; however, the drug was not active in a phase 2 clinical trial ${ }^{83}$.

\section{Xenograft models in sarcomas}

Sarcomas including rhabdomyosarcoma, Ewing sarcoma, osteosarcoma, rhabdomyosarcoma, desmoplastic small round-cell tumors, high-grade sarcomas, retinoblastoma, adrenocortical carcinomas, and rare solid tumors have also had xenograft models generated successfully. To improve understanding of the 
complexity of these pediatric solid tumors and identify drug vulnerabilities, one group generated PDOX models in athymic nude and NSG mice using samples from 168 patients with an overall $45 \%$ engraftment rate $^{86}$. In this large effort, they established 67 PDOXs in 12 solid tumor types and performed molecular characterization using immunohistochemistry (IHC), transmission electron microscopy (TEM), genetic sequencing, epigenetic analysis, and tumor clonal analysis over time $^{86}$. Patient-derived tumors were dissociated and cultured for in vitro drug sensitivity screening, which identified that HDAC and proteasome inhibitors had activity across multiple tumor types and cell lines and that a WEE1 inhibitor called AZD1775 was particularly active in rhabdomyosarcoma cells. Rhabdomyosarcoma PDOXs were then treated with the HDAC inhibitor panobinostat in combination with bortezomib, albeit without response ${ }^{86}$. In contrast, AZD1775 combined with irinotecan and vincristine was more effective than irinotecan and vincristine alone in rhabdomyosarcoma PDOX, leading to an ongoing early phase trial ${ }^{86}$.

In Ewing sarcoma, malignant cells depend upon activity of the EWS-FLI1 transcription factor, making it an attractive target for study. In preclinical models, effective inhibition of this transcription factor's activity required high concentrations of EWS-FLI1 inhibitors ${ }^{88,137}$. In a phase $1 / 2$ clinical trial of the EWS-FLI1 inhibitor mithramycin, comparable concentrations could not be achieved because of hepatoxicty ${ }^{138}$. More recent studies using Ewing's sarcoma xenografts in nude mice have demonstrated differentiation of Ewing sarcoma tumors with the use of another EWS-FLI1 inhibitor, trabectedin, in combination with irinotecan, prompting interest in this combination in clinical trials ${ }^{88}$.

\section{Xenograft models in central nervous system malignancies}

Central nervous system (CNS) malignancies have been particularly difficult to study in preclinical models. Nevertheless, PDX and PDOX models have been generated for multiple CNS malignancies. In general, PDOX models with intracranial tumor placement have the advantage of recapitulating the blood-brain barrier but the difficulty of monitoring disease progression over time. PDX flank models can be monitored more easily but do not have the same blood-brain barrier seen in parent tumors, which weakens the applicability of the model. Intra-orbital CNS tumor xenografts allow for engraftment in an immune-privileged site that can be monitored but with small tumor volumes ${ }^{139}$.

In medulloblastoma, the most common CNS tumor in children, patient-derived samples have been successfully xenografted into the flanks of nude mice and could be serially passaged in vivo ${ }^{140,141}$. These studies have allowed for the study of medulloblastoma tumor biology and molecular characterization, leading to a greater understanding of the disease ${ }^{141,142}$. PDX and PDOX mouse models now exist for all four major molecular groups of medulloblastoma ${ }^{19}$. In one study, medulloblastoma samples with $\mathrm{SHH}$ aberrations were treated with the smoothened inhibitor vismodegib and had prolonged survival compared to a vehicle-treated control $^{90}$. For high-grade gliomas, mice have also been xenografted with patient samples for preclinical investigation of novel therapies. For example, high-grade gliomas with EGFR amplification were xenografted and treated with the EGFR inhibitor erlotinib, demonstrating improved survival relative to control $^{90}$. Vismodegib and erlotinib remain under clinical investigation in pediatric patients with medulloblastoma and high-grade gliomas (NCT01878617 and NCT00602667).

Xenograft models of glioblastoma multiforme (GBM) and other high-grade gliomas have also been developed ${ }^{143,144}$. Orthotopic and flank injection of patient-derived glioblastoma stem cells were used to show that the stem cells are capable of differentiating into endothelial cells, providing a source of vascularization for the highly aggressive tumor. This endothelial differentiation was therefore postulated as a therapeutic target to prevent tumor angiogenesis in the treatment of $\mathrm{GBM}^{145}$. GBM models have also been used for preclinical testing of a number of novel therapies, including STAT3 inhibitors, NAMPT inhibitors, radiation + checkpoint inhibitors, EGFR inhibitors, and PARP inhibitors ${ }^{146-151}$.

\section{Xenograft consortia and targeted treatments}

A number of groups have developed robust consortia of PDX models that allow for the investigation of disease biology through molecular characterization, drug screening, and highthroughput testing of therapies ${ }^{16,86,90}$. One such example is the pediatric preclinical testing consortium (PPTC), which has generated over 390 patient-derived tumor xenografts that have been molecularly characterized by single nucleotide polymorphism (SNP) analysis, comparative genomic hybridization $(\mathrm{CGH})$, whole exome/whole transcriptome analysis, and short tandem repeat testing ${ }^{16,152,153}$. Other large xenograft consortia include the Childhood Solid Tumor Network, Children's Oncology Group Cell Culture and Xenograft Repository, Targeting of Resistance in Pediatric Oncology Program, IMI2 ITCC-P4, and the European PDX Consortium.

One group generated a PDX biobank of drug-resistant ALL samples from 60 patients with high-risk leukemia ${ }^{72}$. These leukemias were characterized extensively with genomic profiling to ensure the engrafted tumors maintained the genetic alterations found in the primary patient samples. Venetoclax was shown to be highly active in KMT2A-r ALL and TCF3HLF ALL in vitro. Dasatinib and venetoclax were demonstrated to have a high level of activity against a group of T-ALL samples in vitro. The in vitro activity was confirmed in PDX models in NSG mice, and, as a result, a patient with refractory T-ALL was treated with dasatinib and achieved a 5-month remission $^{72}$. The PPTC has also reported prediction of clinical efficacy with its drug screening and PDX models ${ }^{52}$. The molecular profiling, drug sensitivity screening, and in vivo xenograft testing that these consortia provide allows for powerful and predictive modeling for molecularly defined malignancies.

Preclinical PDX biobanks can help to guide the determination of which drugs should have the highest priority for introduction 
into clinical trials for specific subsets of patients. There are several cohorts running clinical trials that first genetically profile tumor samples and then enroll subjects on treatment arms based on their profiling results and existing preclinical and/or clinical efficacy data. The NCI-COG Pediatric MATCH is a large phase 2 trial that provides targeted therapies for relapsed/ refractory pediatric solid tumors, NHL, and histiocytic disorders on the basis of patient tumor genetic features. This study currently has 10 treatment arms and has a match rate of $24 \%$, which is much higher than the predicted $10 \%{ }^{154}$. Other similar programs include the MAPPYACTS, SMPaeds, iTHER, INFORM, and TARGET trials ${ }^{155}$. Molecularly targeted clinical trials are expected to grow as molecular targets and drugs continue to be developed through in vitro tumor characterization and PDX modeling.

\section{Xenograft models for study of immunotherapies}

Cancer immunotherapies have demonstrated substantial efficacy for certain malignancies that have been refractory to traditional treatment modalities and have enormous potential for improving outcomes in others. However, many types of cancer have been immunotherapy refractory, prompting active preclinical research in xenograft models. The study of immunotherapies in these models presents a unique challenge in that their efficacy and toxicities are typically most accurately modeled in animals with intact immune systems.

\section{Monoclonal antibodies}

A classic example demonstrating the need for an intact immune system for the preclinical study of immunotherapies was an experiment evaluating the efficacy of the anti-CD20 monoclonal antibody (moAb) rituximab in SCID mice xenografted with CD20+ Raji lymphoma cells, with or without depletion of NK-cells and neutrophils. NK-cell and neutrophil-replete mice that were treated with rituximab had greater survival when compared with NK-cell or neutrophil-depleted mice treated with rituximab and NK-cell/neutrophil-replete mice treated with placebo, illustrating the importance of neutrophils and NK-cells for antibody-dependent cellular cytotoxicity (ADCC) $)^{156}$. Another study evaluated the role of $\mathrm{Fc} \gamma$ receptors in the efficacy of the anti-HER2 moAbs trastuzumab and rituximab in breast cancer- or lymphoma-xenografted mice, respectively. $\mathrm{BALB} / \mathrm{c}$ nude mice were modified to be deficient in the activation Fc $\gamma$ receptors Fc $\gamma R I$ and Fc $\gamma$ RIII or the inhibitory receptor Fc $\gamma$ RIIB. These mice and wild-type BALB/c nude mice were xenografted with HER2 ${ }^{+}$breast cancer cells or $\mathrm{CD}_{2} 0^{+}$Raji lymphoma cells. They found that the greatest protection offered by the moAbs was in mice that were deficient in FcyRIIB but with intact Fc $\gamma$ RI and Fc $\gamma$ RIII. No protection was offered by moAbs in Fc $\gamma$ RI- and Fc $\gamma$ RIII-deficient mice ${ }^{69}$. SCID mice and nude mice provided good models for the study of these therapies because of their largely intact innate immune systems, which mediate the ADCC response. However, these mice do not completely recapitulate an intact immune system, and their innate immunity is murine in origin.

\section{Chimeric antigen receptor technology}

CAR T-cells directed against CD19 were initially studied in syngeneic mouse models with murine-derived lymphoma cells and murine CAR T-cells. Syngeneic models have the advantage of being immunocompetent, with the disadvantages of diminished murine CAR T-cell persistence (when compared with human CAR T-cells) and the use of murine instead of human tissues $^{38,157}$. Illustrating this, in one syngeneic model, BALB/c mice xenografted with murine lymphoma cells did show cytokine elevation (IFN- $\gamma$ and TNF- $\alpha$ ) when treated with murine CAR T-cells, suggesting systemic inflammation secondary to CAR T-cell treatment. However, this did not match the cytokine release pattern later seen in patients with cytokine release syndrome (CRS), one of the main toxicities associated with CAR T-cells ${ }^{158}$. Xenograft experiments testing CAR T-cells against B-ALL are now most often carried out in NSG mice, allowing study of the human CAR T-cells against human leukemia ${ }^{157}$. In these models, CD19-directed CAR T-cells demonstrated profound anti-leukemia efficacy, but, owing to the immunodeficiency in these mice, CRS was not observed ${ }^{157}$.

The successes seen with CD19-directed CAR T-cells in preclinical models translated into robust clinical responses in relapsed/ refractory pediatric B-ALL patients treated with the CD19directed CAR T-cell product tisagenlecleucel (Kymriah) ${ }^{39,40}$. Based on these results, tisagenlecleucel became the first FDAapproved cell-based gene therapy in 2017. Two major toxicities experienced by CAR T-cell recipients are CRS, a syndrome characterized by severe systemic inflammation with elevations in IL- 6 and IFN- $\gamma$ that occurs in the vast majority of patients treated, and neurotoxicity, which can range in severity from seizures to death ${ }^{40}$. CRS and neurotoxicity were not observed in early models because of lack of human immune cells and lack of murine tissue responsiveness to human cytokines ${ }^{40,41}$.

Now, improved preclinical models have been developed that allow for the prediction of immune-mediated toxicities of CAR T-cells and serve as excellent tools for ongoing research in this area. One example is the use of humanized NSG mice made transgenic for human cytokine production to promote human immune system development (NSGS or NSG-SGM3 mice). Humanized NSGS mice were xenografted with patient-derived ALL, then treated with CAR T-cells derived from the humanized lymphocytes ${ }^{41}$. Interestingly, the treated mice demonstrated neurotoxicity and CRS differentially mediated by IL- 1 and IL-6, while the same effects had not been shown in NSG mice without the transgenic cytokine expression $^{41}$. Furthermore, human monocytes and macrophages were found to be the main source of these cytokines, explaining why previous immunodeficient CAR T-cell-treated xenograft and syngeneic models may not have experienced these toxicities ${ }^{41}$. Finally, an IL-1-directed antibody, anakinra, was used to treat mice with neurotoxicity, reducing its severity and lethality $^{41}$. Such a model will likely help to predict toxicities in future studies of CAR T-cell therapies.

Humanized NSG mice have also been used to generate ALL and CAR T-cells from the same human tissues (autologous CAR T-cells), as is typically done in the clinic. With one method, irradiated NSG mice were xenografted with human fetal thymus and $\mathrm{CD}_{4} 4^{+}$fetal liver cells (FLCs) ${ }^{159}$. CD34 ${ }^{+}$FLCs were also transduced with a retrovirus containing the MLL-AF9 
oncogene to create an ALL cell line that was then xenografted into the humanized NSGs. CAR T-cells were then created from humanized T-cells derived from the humanized mice, generating a humanized autologous CAR T-cell mouse model that represents the current therapeutic approach of most CAR T-cell products. However, the system did not recapitulate CRS, which was thought to be due to the lack of human cytokine transgene expression $^{159}$.

A long-term goal of CAR therapy is to produce CAR T-cells in vivo. To test this in preclinical models, NSG mice were xenografted with the $\mathrm{Raji}^{+}$cell line, human B-cell-depleted peripheral blood mononuclear cells (PBMCs), and lentivirus targeted to $\mathrm{CD}^{+}$T-cells containing CAR19 genes ${ }^{160}$. These experiments showed that Raji ${ }^{+}$lymphoblastic cells and normal CD19+ cells can be eliminated via the administration of lentivirus containing CAR $\mathrm{T}$ genes in vivo, with elevation of cytokines similar to CRS in some animals ${ }^{160}$.

The use of CAR technology in solid tumors has had less clinical success so far and remains an area of active investigation. CAR T-cells targeting GD2 and L1-CAM have been generated for use in neuroblastoma with good results in mouse models but limited success in clinical trials ${ }^{75}$. Based on promising preclinical evidence in xenograft models, CAR NK T-cells (NKTs) are beginning to be tested in solid tumors including neuroblastoma $^{161}$. Furthermore, NKTs enriched for CD62L expression via artificial antigen-presenting cell-mediated expansion have been used to produce CAR NKTs and showed that CD62 $\mathrm{L}^{+}$CAR NKTs have fivefold longer persistence in host mice than non-CD62 $\mathrm{L}^{-}$CAR NKTs, suggesting another promising avenue for $\mathrm{study}^{162}$. Numerous studies have explored methods for enhancing the efficacy of CAR T-cells in the solid TME. T-cell exhaustion and tumor PD-L1/2 expression have been postulated as limiting factors for the efficacy of CAR T-cells in the solid $\mathrm{TME}^{163}$. Enhancing CAR T-cell function with immunomodulators including the TGF- $\beta$ inhibitor galunisertib, checkpoint inhibitors, and lenalidomide have been tried with promising preclinical results ${ }^{163,164}$. CAR T-cells targeting B7-H3 (CD276), a checkpoint molecule highly expressed on pediatric solid tumor and brain tumors, have been generated for use in preclinical orthotopic xenograft models of osteosarcoma, Ewing sarcoma, and medulloblastoma. Treatment with CAR T-cells targeting B7-H3 in preclinical models was promising, demonstrating tumor regression and improved survival in all three tumor types ${ }^{165}$.

\section{Checkpoint inhibitors}

Checkpoint inhibitors represent another arm of immunotherapy with exceptional clinical activity in select malignancies including melanoma and HL yet no activity in other diseases. Checkpoint inhibitors function by increasing immune activation against a tumor; therefore, both an intact immune system and a TME are required. Checkpoint inhibitors have been studied in syngeneic murine models. These models have the advantage of intact immune systems but are limited by rapid murine tumor growth, absence of human targets, and lack of genetic complexity ${ }^{7}$. Humanized mice have therefore gained significant importance in the study of these agents.

Humanized models using NSG or RAG1 or $2^{-/-}$, IL2R $\gamma^{\text {null }}$ mice engrafted with human PBMCs and human-derived malignancies have been used to study checkpoint immunotherapy. One group xenografted humanized mice with human colorectal cancer or gastric cancer cells and treated them with nivolumab, a PD-1 inhibitor, and urelumab, a 4-1BB (CD137) agonist, alone and in combination, to evaluate their anti-tumor properties ${ }^{65}$. These studies demonstrated that mice treated with urelumab/nivolumab combination had increased T-cell IFN- $\gamma$ expression, increased tumor $\mathrm{CD}^{+} \mathrm{T}$-cell/T-regulatory cell ratios, and slowed colon cancer and gastric cancer tumor growth compared with untreated controls $^{65}$. These studies suggest humanized mice may be relevant models for the study of checkpoint inhibitors in pediatric cancers. One major limitation of humanized mouse models in the study of checkpoint inhibitors is the xGVHD that frequently develops, with human T-cell infiltration into the liver, spleen, and lungs. xGVHD does limit the durations of studies but can be overcome with CD4 depletion ${ }^{65}$.

The immune PDX model provides another method for the study of checkpoint inhibitors. In this model, human tumors with associated tumor-infiltrating lymphocytes (TILs) are orthotopically placed in immunodeficient mice. Notably, these models can be used only as first passage models and only have a preserved immune system-tumor interaction for approximately 3-4 weeks post engraftment ${ }^{7,166}$.

Another model useful in the study of checkpoint inhibitors is the $\mathrm{BALB} / \mathrm{c} \mathrm{RAG} 2^{--} \mathrm{IL} 2 \mathrm{R} \gamma^{\text {null }}$ mouse with transgenic expression of M-CSF, IL-3, GM-CSF, thrombopoietin, and SIRPa, for human immune system development, and are called MI(S)TRG. Humanized MI(S)TRG mice given human CD34+ cells were xenografted with human melanoma cell line Me290 and demonstrated human macrophage infiltration into xenografted melanoma, more closely recapitulating a human $\mathrm{TME}^{53}$. Given that the lack of an innate immune system has been a limitation of preclinical immunotherapeutic investigations, transgenic expression of human cytokines offers an important method for assessing immunotherapies with a more intact immune system.

While the above models have their limitations, they provide a closer look into human immune response to human malignancy. The use of these xenograft models with combination therapies (checkpoint inhibitors + conventional chemotherapy or checkpoint inhibitors + adoptive cell therapy) are likely to provide useful information about this expanding area of investigation in cancer immunotherapy.

\section{Conclusions}

The increasing understanding of the influence of genetics, epigenetics, and proteomics on human cancer behavior, combined with the development of PDX biobanks, comprehensive molecular profiling, high-throughput drug screening, and 
xenograft models allow us to study a wider variety of cancers in a more predictive way than ever before. Persistent challenges include the influence of mouse stroma-infiltrating human tumors, $x G V H D$, difficulties recapitulating the human immune system and TME, genetic drift, and clonal evolution with serial passage of cancer cells. As precision medicine and immunotherapies have become more commonplace, accurate model systems remain of utmost importance.
1. Street W: Cancer Facts \& Figures 2020. 1930; 76. Reference Source

2. Westhoff MA, Marschall N, Grunert M, et al:: Cell death-based treatment of childhood cancer. Cell Death Dis. 2018; 9(2): 116. PubMed Abstract | Publisher Full Text | Free Full Text

3. Diller L, Chow EJ, Gurney JG, et al:: Chronic disease in the Childhood Cance Survivor Study cohort: A review of published findings. J Clin Oncol. 2009; 27(14): 2339-55

PubMed Abstract | Publisher Full Text | Free Full Text

4. Jung J: Human tumor xenograft models for preclinical assessment of anticancer drug development. Toxicol Res. 2014; 30(1): 1-5. PubMed Abstract | Publisher Full Text | Free Full Text

5. Hidalgo M, Amant F, Biankin AV, et al:: Patient-derived xenograft models: An emerging platform for translational cancer research. Cancer Discov. 2014; 4(9): 998-1013.

PubMed Abstract | Publisher Full Text | Free Full Text

6. Tentler JJ, Tan AC, Weekes CD, et al:: Patient-derived tumour xenografts as models for oncology drug development. Nat Rev Clin Oncol. 2012; 9(6): 338-50. PubMed Abstract | Publisher Full Text | Free Full Text

7. Sanmamed MF, Chester C, Melero I, et al:: Defining the optimal murine models to investigate immune checkpoint blockers and their combination with other immunotherapies. Ann Oncol. 2016; 27(7): 1190-8. PubMed Abstract | Publisher Full Text

8. Hynds RE, Vladimirou E, Janes SM: The secret lives of cancer cell lines. Dis Model Mech. 2018; 11(11): dmm037366. PubMed Abstract | Publisher Full Text | Free Full Text

9. Borgmann A, Baldy C, von Stackelberg A, et al.: Childhood all blasts retain phenotypic and genotypic characteristics upon long-term serial passage in NOD/SCID mice. Pediatr Hematol Oncol. 2000; 17(8): 635-50. PubMed Abstract | Publisher Full Text

10. Rygaard J, Povlsen CO: Heterotransplantation of a human malignant tumour to "Nude" mice. Acta Pathol Microbiol Scand. 1969; 77(4): 758-60. PubMed Abstract | Publisher Full Text

11. Bosma GC, Custer RP, Bosma MJ: A severe combined immunodeficiency mutation in the mouse. Nature. 1983; 301(5900): 527-30. PubMed Abstract | Publisher Full Text

12. Fidler IJ: Rationale and methods for the use of nude mice to study the biology and therapy of human cancer metastasis. Cancer Metastasis Rev. 1986; 5(1): 29-49.

PubMed Abstract | Publisher Full Text

13. McCune JM, Namikawa R, Kaneshima H, et al:: The SCID-hu mouse: Murine model for the analysis of human hematolymphoid differentiation and function. Science. 1988; 241(4873): 1632-9.

PubMed Abstract | Publisher Full Text

14. Mosier DE, Gulizia RJ, Baird SM, et al.: Transfer of a functional human immune system to mice with severe combined immunodeficiency. Nature. 1988; 335(6187): 256-9.

PubMed Abstract | Publisher Full Text

15. Grisanzio C, Seeley A, Chang M, et al:: Orthotopic xenografts of $\mathrm{RCC}$ retain histological, immunophenotypic and genetic features of tumours in patients. J Pathol. 2011; 225(2): 212-21.

PubMed Abstract | Publisher Full Text | Free Full Text

16. Rokita JL, Rathi KS, Cardenas MF, et al.: Genomic Profiling of Childhood Tumor Patient-Derived Xenograft Models to Enable Rational Clinical Trial Design. Cell Rep. 2019; 29(6): 1675-1689.e9. PubMed Abstract | Publisher Full Text | Free Full Text | Faculty Opinions Recommendation

17. Richter-Pechańska P, Kunz JB, Bornhauser B, et al:: PDX models recapitulate the genetic and epigenetic landscape of pediatric T-cell leukemia. EMBO Mol Med. 2018; 10(12): e9443.

PubMed Abstract | Publisher Full Text | Free Full Text |

Faculty Opinions Recommendation
18. Hanahan D: Transgenic mice as probes into complex systems. Science. 1989; 246(4935): 1265-75.

PubMed Abstract | Publisher Full Text

19. Roussel MF, Stripay JL: Modeling pediatric medulloblastoma. Brain Pathol. 2020; 30(3): 703-12.

PubMed Abstract | Publisher Full Text | Free Full Text

20. Brendel C, Rio P, Verhoeyen E: Humanized mice are precious tools for evaluation of hematopoietic gene therapies and preclinical modeling to move towards a clinical trial. Biochem Pharmacol. 2020; 174: 113711. PubMed Abstract | Publisher Full Text

21. Nath S, Devi GR: Three-dimensional culture systems in cancer research: Focus on tumor spheroid model. Pharmacol Ther. 2016; 163: 94-108. PubMed Abstract | Publisher Full Text | Free Full Text

22. Kamel-Reid S, Letarte M, Sirard C, et al:: A model of human acute lymphoblastic leukemia in immune-deficient SCID mice. Science. 1989; 246(4937): 1597-600. PubMed Abstract | Publisher Full Text

23. Morland BJ, Boehm D, Flavell SU, et al.: Immunotoxin studies in a model of human T-cell acute lymphoblastic leukemia developed in severe combined immune-deficient mice. Cell Biophys. 1994; 24-25: 315-29.

PubMed Abstract | Publisher Full Text

24. Uckun FM, Sather H, Reaman G, et al.: Leukemic cell growth in SCID mice as a predictor of relapse in high-risk B-lineage acute lymphoblastic leukemia. Blood. 1995; 85(4): 873-8.

PubMed Abstract | Publisher Full Text

25. Uckun FM, Manivel C, Arthur D, et al.: In vivo efficacy of B43 (anti-CD19)pokeweed antiviral protein immunotoxin against human pre-B cell acute lymphoblastic leukemia in mice with severe combined immunodeficiency. Blood. 1992; 79(9): 2201-14.

PubMed Abstract | Publisher Full Text

26. Lock RB, Liem N, Farnsworth ML, et al.: The nonobese diabetic/severe combined immunodeficient (NOD/SCID) mouse model of childhood acute lymphoblastic leukemia reveals intrinsic differences in biologic characteristics at diagnosis and relapse. Blood. 2002; 99(11): 4100-8. PubMed Abstract | Publisher Full Text

27. Steele JPC, Clutterbuck RD, Powles RL, et al:: Growth of Human T-Cell Lineage Acute Leukemia in Severe Combined Immunodeficiency (SCID) Mice and Nonobese Diabetic SCID Mice. Blood. 1997; 90(5): 2015-9. PubMed Abstract | Publisher Full Text

28. Baersch G, Möllers T, Hötte A, et al:: Good engraftment of B-cell precursor ALL in NOD-SCID mice. Klin Padiatr. 1997; 209(4): 178-85. PubMed Abstract | Publisher Full Text

29. Ito M, Hiramatsu H, Kobayashi K, et al.: NOD/SCID/gamma(c)(null) mouse: An excellent recipient mouse model for engraftment of human cells. Blood. 2002 100(9): 3175-82.

PubMed Abstract | Publisher Full Text

30. Gopalakrishnapillai A, Kolb EA, Dhanan P, et al:: Generation of Pediatric Leukemia Xenograft Models in NSG-B2m Mice: Comparison with NOD/SCID Mice. Front Oncol. 2016; 6: 162 .

PubMed Abstract | Publisher Full Text | Free Full Text

31. Dreier T, Lorenczewski G, Brandl C, et al:: Extremely potent, rapid and costimulation-independent cytotoxic T-cell response against lymphoma cells catalyzed by a single-chain bispecific antibody. Int J Cancer. 2002; 100(6): 690-7.

PubMed Abstract | Publisher Full Text

32. Locatelli F, Zugmaier G, Bader P, et al.: Blinatumomab in Pediatric Patients with Relapsed/Refractory B-Cell Precursor and Molecularly Resistant Acute Lymphoblastic Leukemia (R/R ALL): Updated Analysis of 110 Patients Treated in an Expanded Access Study (RIALTO). Blood. 2019; 134(Supplement_1): 1294. Publisher Full Text

33. Schlereth B, Quadt C, Dreier T, et al.: T-cell activation and B-cell depletion in chimpanzees treated with a bispecific anti-CD19/anti-CD3 single-chain antibody construct. Cancer Immunol Immunother. 2006; 55(5): 503-14. PubMed Abstract | Publisher Full Text 
34. Nagorsen D, Kufer P, Baeuerle PA, et al.: Blinatumomab: A historical perspective. Pharmacol Ther. 2012; 136(3): 334-42. PubMed Abstract | Publisher Full Text

35. Pan R, Hogdal LJ, Benito JM, et al:: Selective BCL-2 inhibition by ABT-199 causes on-target cell death in acute myeloid leukemia. Cancer Discov. 2014; 4(3): 362-75.

PubMed Abstract | Publisher Full Text | Free Full Tex

36. Wei AH, Strickland SA, Hou JZ, et al:: Venetoclax Combined With Low-Dose Cytarabine for Previously Untreated Patients With Acute Myeloid Leukemia: Results From a Phase Ib/II Study. J Clin Oncol. 2019; 37(15): 1277-84. PubMed Abstract | Publisher Full Text | Free Full Text | Faculty Opinions Recommendation

37. Place $\mathrm{AE}$, Goldsmith $\mathrm{K}$, Bourquin JP, et al.: Accelerating drug development in pediatric cancer: A novel Phase I study design of venetoclax in relapsed/ refractory malignancies. Future Oncol. 2018; 14(21): 2115-29. PubMed Abstract | Publisher Full Text

38. Kochenderfer JN, Yu Z, Frasheri D, et al.: Adoptive transfer of syngeneic T cells transduced with a chimeric antigen receptor that recognizes murine CD19 can eradicate lymphoma and normal B cells. Blood. 2010; 116(19): 3875-86. PubMed Abstract | Publisher Full Text | Free Full Text

39. Grupp SA, Kalos M, Barrett D, et al:: Chimeric antigen receptor-modified T cells for acute lymphoid leukemia. N Engl J Med. 2013; 368(16): 1509-18. PubMed Abstract | Publisher Full Text | Free Full Text

40. Maude SL, Laetsch TW, Buechner J, et al.: Tisagenlecleucel in Children and Young Adults with B-Cell Lymphoblastic Leukemia. N Engl J Med. 2018; 378(5): 439-48.

PubMed Abstract | Publisher Full Text | Free Full Text |

Faculty Opinions Recommendation

41. Norelli M, Camisa B, Barbiera G, et al:: Monocyte-derived IL-1 and IL-6 are differentially required for cytokine-release syndrome and neurotoxicity due to CAR T cells. Nat Med. 2018; 24(6): 739-48.

PubMed Abstract | Publisher Full Text | Faculty Opinions Recommendation

42. Barrett DM: Improving CAR T cell immunotherapy-mediated remissions for pediatric leukemia. J Clin Invest. 2019; 129(5): 1842-4.

PubMed Abstract | Publisher Full Text | Free Full Text

43. Wu Y, Yu XZ: Modelling CAR-T therapy in humanized mice. EBioMedicine. 2019; 40: 25-6.

PubMed Abstract | Publisher Full Text | Free Full Text

44. Horne GA, Stobo J, Kelly C, et al.: A randomised phase II trial of hydroxychloroquine and imatinib versus imatinib alone for patients with chronic myeloid leukaemia in major cytogenetic response with residual disease. Leukemia. 2020; 34(7): 1775-86.

PubMed Abstract | Publisher Full Text | Free Full Text

45. Kantarjian H, Stein A, Gökbuget N, et al.: Blinatumomab versus Chemotherapy for Advanced Acute Lymphoblastic Leukemia. N Engl J Med. 2017; 376(9): 836-47.

PubMed Abstract | Publisher Full Text | Free Full Text | Faculty Opinions Recommendation

46. Jones L, McCalmont H, Evans K, et al.: Preclinical activity of the antibodydrug conjugate denintuzumab mafodotin (SGN-CD19A) against pediatric acu lymphoblastic leukemia xenografts. Pediatr Blood Cancer. 2019; 66(8): e27765. PubMed Abstract | Publisher Full Text | Free Full Text | Faculty Opinions Recommendation

47. Sawai CM, Freund J, Oh P, et al.: Therapeutic targeting of the cyclin D3: CDK4/6 complex in T cell leukemia. Cancer Cell. 2012; 22(4): 452-65. PubMed Abstract | Publisher Full Text | Free Full Text | Faculty Opinions Recommendation

48. Tatarek J, Cullion K, Ashworth T, et al:: Notch1 inhibition targets the leukemiainitiating cells in a Tal1/Lmo2 mouse model of T-ALL. Blood. 2011; 118(6): 1579-90.

PubMed Abstract | Publisher Full Text | Free Full Text

49. Maude SL, Dolai S, Delgado-Martin C, et al.: Efficacy of JAK/STAT pathway inhibition in murine xenograft models of early T-cell precursor (ETP) acute lymphoblastic leukemia. Blood. 2015; 125(11): 1759-67. PubMed Abstract | Publisher Full Text | Free Full Text

50. Jones $\mathrm{CL}$, Gearheart CM, Fosmire S, et al:: MAPK signaling cascades mediate distinct glucocorticoid resistance mechanisms in pediatric leukemia. Blood. 2015; 126(19): 2202-12.

PubMed Abstract | Publisher Full Text | Free Full Text | Faculty Opinions Recommendation

51. Klossowski S, Miao H, Kempinska K, et al:: Menin inhibitor MI-3454 induces remission in MLL1-rearranged and NPM1-mutated models of leukemia. J Clin Invest. 2020; 130(2): 981-97.

PubMed Abstract | Publisher Full Text | Free Full Text |

Faculty Opinions Recommendation

52. Jones $\mathrm{L}, \mathrm{Carol} \mathrm{H}$, Evans $\mathrm{K}$, et al:: A review of new agents evaluated against pediatric acute lymphoblastic leukemia by the Pediatric Preclinical Testing Program. Leukemia. 2016; 30(11): 2133-41.

PubMed Abstract | Publisher Full Text
53. Rongvaux A, Willinger T, Martinek J, et al:: Development and function of human innate immune cells in a humanized mouse model. Nat Biotechnol. 2014; 32(4): 364-72.

PubMed Abstract | Publisher Full Text | Free Full Text |

Faculty Opinions Recommendation

54. McNeil MJ, Parisi MT, Hijiya N, et al.: Clinical and Radiographic Response of Extramedullary Leukemia in Patients Treated With Gemtuzumab Ozogamicin J Pediatr Hematol Oncol. 2019; 41(3): e174-e176.

PubMed Abstract | Publisher Full Text | Faculty Opinions Recommendation

55. Han L, Zhang Q, Dail M, et al.: Concomitant targeting of BCL2 with venetoclax and MAPK signaling with cobimetinib in acute myeloid leukemia models. Haematologica. 2020; 105(3): 697-707.

PubMed Abstract | Publisher Full Text | Free Full Text |

Faculty Opinions Recommendation

56. Zarrinkar PP, Gunawardane RN, Cramer MD, et al.: AC220 is a uniquely potent and selective inhibitor of FLT3 for the treatment of acute myeloid leukemia (AML). Blood. 2009; 114(14): 2984-92.

PubMed Abstract | Publisher Full Text | Free Full Text

57. Krivtsov AV, Evans K, Gadrey JY, et al:: A Menin-MLL Inhibitor Induces Specific Chromatin Changes and Eradicates Disease in Models of MLLRearranged Leukemia. Cancer Cell. 2019; 36(6): 660-673.e11. PubMed Abstract | Publisher Full Text | Free Full Text | Faculty Opinions Recommendation

58. Scott MT, Korfi K, Saffrey P, et al.: Epigenetic Reprogramming Sensitizes CML Stem Cells to Combined EZH2 and Tyrosine Kinase Inhibition. Cancer Discov. 2016; 6(11): 1248-57.

PubMed Abstract | Publisher Full Text | Free Full Text

59. Clarke CJ, Holyoake TL: Preclinical approaches in chronic myeloid leukemia: from cells to systems. Exp Hematol. 2017; 47: 13-23.

PubMed Abstract | Publisher Full Text | Free Full Text

60. Cullinane $\mathrm{C}$, Natoli A, Hui $\mathrm{Y}$, et al.: Preclinical evaluation of nilotinib efficacy in an imatinib-resistant KIT-driven tumor model. Mol Cancer Ther. 2010; 9(5): 1461-8.

PubMed Abstract | Publisher Full Text

61. Mitchell R, Hopcroft LEM, Baquero P, et al:: Targeting BCR-ABL-Independent TKI Resistance in Chronic Myeloid Leukemia by mTOR and Autophagy Inhibition. J Natl Cancer Inst. 2018; 110(5): 467-78.

PubMed Abstract | Publisher Full Text | Free Full Text |

Faculty Opinions Recommendation

62. Ansell SM: Brentuximab vedotin. Blood. 2014; 124(22): 3197-200. PubMed Abstract | Publisher Full Text

63. LaCasce AS, Bociek RG, Sawas A, et al.: Three-year outcomes with brentuximab vedotin plus bendamustine as first salvage therapy in relapsed or refractory Hodgkin lymphoma. Br J Haematol. 2020; 189(3): e86-e90. or refractory Hodgkin lymphoma. Br J Haematol. 2020; 189(3): e86-e90.
PubMed Abstract | Publisher Full Text | Faculty Opinions Recommendation

64. Ju W, Zhang M, Wilson KM, et al:: Augmented efficacy of brentuximab vedotin combined with ruxolitinib and/or Navitoclax in a murine model of human Hodgkin's lymphoma. Proc Natl Acad Sci U S A. 2016; 113(6): 1624-9. PubMed Abstract | Publisher Full Text | Free Full Text

65. Sanmamed MF, Rodriguez I, Schalper KA, et al.: Nivolumab and Urelumab Enhance Antitumor Activity of Human T Lymphocytes Engrafted in Rag2 ${ }^{-1-}$

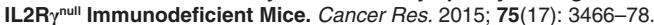
PubMed Abstract | Publisher Full Text

66. Armand P, Engert A, Younes A, et al.: Nivolumab for Relapsed/Refractory Classic Hodgkin Lymphoma After Failure of Autologous Hematopoietic Cell Transplantation: Extended Follow-Up of the Multicohort Single-Arm Phase II CheckMate 205 Trial. J Clin Oncol. 2018; 36(14): 1428-39. PubMed Abstract | Publisher Full Text | Free Full Text | Faculty Opinions Recommendation

67. Hao Y, Chapuy B, Monti S, et al:: Selective JAK2 inhibition specifically decreases Hodgkin lymphoma and mediastinal large B-cell lymphoma growth in vitro and in vivo. Clin Cancer Res. 2014; 20(10): 2674-83. PubMed Abstract | Publisher Full Text | Free Full Text

68. Lee S, Shah T, Yin C, et al.: Ruxolitinib significantly enhances in vitro apoptosis in Hodgkin lymphoma and primary mediastinal B-cell lymphoma and survival in a lymphoma xenograft murine model. Oncotarget. 2018; 9(11): 9776-88.

PubMed Abstract | Publisher Full Text | Free Full Text |

Faculty Opinions Recommendation

69. Clynes RA, Towers TL, Presta LG, et al:: Inhibitory Fc receptors modulate in vivo cytotoxicity against tumor targets. Nat Med. 2000; 6(4): 443-6. PubMed Abstract | Publisher Full Text

70. Herter S, Herting F, Mundigl O, et al.: Preclinical activity of the type II CD20 antibody GA101 (obinutuzumab) compared with rituximab and ofatumumab in vitro and in xenograft models. Mol Cancer Ther. 2013; 12(10): 2031-42. PubMed Abstract | Publisher Full Text

71. $\mathrm{GeX}$, Chen J, Li L, et al:: Midostaurin potentiates rituximab antitumor activity in Burkitt's lymphoma by inducing apoptosis. Cell Death Dis. 2018; 
10(1): 8 .

PubMed Abstract | Publisher Full Text | Free Full Text |

Faculty Opinions Recommendation

72. Frismantas V, Dobay MP, Rinaldi A, et al:: Ex vivo drug response profiling detects recurrent sensitivity patterns in drug-resistant acute lymphoblastic leukemia. Blood. 2017; 129(11): e26-e37.

PubMed Abstract | Publisher Full Text | Free Full Text

73. Yu AL, Gilman AL, Ozkaynak MF, et al.: Anti-GD2 antibody with GM-CSF, interleukin-2, and isotretinoin for neuroblastoma. N Engl J Med. 2010; 363(14) 1324-34.

PubMed Abstract | Publisher Full Text | Free Full Text | Faculty Opinions Recommendation

74. Tran HC, Wan Z, Sheard MA, et al:: TGFBR1 Blockade with Galunisertib (LY2157299) Enhances Anti-Neuroblastoma Activity of the Anti-GD2 Antibody Dinutuximab (ch14.18) with Natural Killer Cells. Clin Cancer Res. 2017; 23(3): 804-13.

PubMed Abstract | Publisher Full Text | Free Full Text

75. Richards RM, Sotillo E, Majzner RG: CAR T Cell Therapy for Neuroblastoma. Front Immunol. 2018; 9: 2380.

PubMed Abstract | Publisher Full Text | Free Full Text

76. Heczey A, Liu D, Tian G, et al:: Invariant NKT cells with chimeric antigen receptor provide a novel platform for safe and effective cance immunotherapy. Blood. 2014; 124(18): 2824-33. PubMed Abstract | Publisher Full Text | Free Full Text

77. Bresler SC, Weiser DA, Huwe PJ, et al:: ALK mutations confer differential oncogenic activation and sensitivity to ALK inhibition therapy in neuroblastoma. Cancer Cell. 2014; 26(5): 682-94. PubMed Abstract | Publisher Full Text | Free Full Text

78. Wang HQ, Halilovic E, Li X, et al.: Combined ALK and MDM2 inhibition increases antitumor activity and overcomes resistance in human ALK mutan neuroblastoma cell lines and xenograft models. eLife. 2017; 6: e17137. PubMed Abstract | Publisher Full Text | Free Full Text

79. Tsoli M, Wadham C, Pinese M, et al:: Integration of genomics, high throughput drug screening, and personalized xenograft models as a novel precision medicine paradigm for high risk pediatric cancer. Cancer Biol Ther. 2018; 19(12): 1078-87. PubMed Abstract | Publisher Full Text | Free Full Text | Faculty Opinions Recommendation

80. Townsend EC, Murakami MA, Christodoulou A, et al.: The Public Repository of Xenografts Enables Discovery and Randomized Phase II-like Trials in Mice. Cancer Cell. 2016; 29(4): 574-86.

PubMed Abstract | Publisher Full Text | Free Full Text

81. Guan J, Tucker ER, Wan H, et al:: The ALK inhibitor PF-06463922 is effective as a single agent in neuroblastoma driven by expression of ALK and MYCN. Dis Model Mech. 2016; 9(9): 941-52.

PubMed Abstract | Publisher Full Text | Free Full Text

82. Richman SA, Nunez-Cruz S, Moghimi B, et al:: High-Affinity GD2-Specific CAR T Cells Induce Fatal Encephalitis in a Preclinical Neuroblastoma Model. Cancer Immunol Res. 2018; 6(1): 36-46.

PubMed Abstract | Publisher Full Text | Free Full Text

83. Pode-Shakked N, Shukrun R, Mark-Danieli M, et al:: The isolation and characterization of renal cancer initiating cells from human Wilms' tumour xenografts unveils new therapeutic targets. EMBO Mol Med. 2013; 5(1): 18-37. PubMed Abstract | Publisher Full Text | Free Full Text

84. Zhang B, Wang Z: [Human cytotoxic T lymphocyte responses specific to the DNA vaccine of Wilms' tumor gene product]. Nan Fang Yi Ke Da Xue Xue Bao. 2009; 29(7): 1348-50. PubMed Abstract

85. Kolb EA, Houghton PJ, Kurmasheva RT, et al:: Preclinical evaluation of the combination of AZD1775 and irinotecan against selected pediatric solid tumors: A Pediatric Preclinical Testing Consortium report. Pediatr Blood Cancer. 2020; 67(5): e28098. PubMed Abstract | Publisher Full Text | Faculty Opinions Recommendation

86. C Stewart E, Federico SM, Chen X, et al.: Orthotopic patient-derived xenografts of paediatric solid tumours. Nature. 2017; 549(7670): 96-100. PubMed Abstract | Publisher Full Text | Free Full Text | Faculty Opinions Recommendation

87. Grohar PJ, Woldemichael GM, Griffin LB, et al: Identification of an inhibitor of the EWS-FLI1 oncogenic transcription factor by high-throughput screening. J Nat/ Cancer Inst. 2011; 103(12): 962-78. PubMed Abstract | Publisher Full Text | Free Full Text | Faculty Opinions Recommendation

88. Harlow ML, Chasse MH, Boguslawski EA, et al.: Trabectedin Inhibits EWSFLI1 and Evicts SWI/SNF from Chromatin in a Schedule-dependent Manner. Clin Cancer Res. 2019; 25(11): 3417-29. PubMed Abstract | Publisher Full Text | Free Full Text | Faculty Opinions Recommendation

89. Huang H, Han Y, Chen Z, et al:: ML264 inhibits osteosarcoma growth and metastasis via inhibition of JAK2/STAT3 and WNT/ $\beta$-catenin signalling pathways. J Cell Mol Med. 2020; 24(10): 5652-64.

PubMed Abstract | Publisher Full Text | Free Full Text |

Faculty Opinions Recommendation

90. Brabetz S, Leary SES, Gröbner SN, et al:: A biobank of patient-derived pediatric brain tumor models. Nat Med. 2018; 24(11): 1752-61. PubMed Abstract | Publisher Full Text | Faculty Opinions Recommendation

91. Romer JT, Kimura H, Magdaleno S, et al:: Suppression of the Shh pathway using a small molecule inhibitor eliminates medulloblastoma in Ptc1(+/-)p53(-/-) mice. Cancer Cell. 2004; 6(3): 229-40.

PubMed Abstract | Publisher Full Text | Faculty Opinions Recommendation

92. Donawho CK, Luo Y, Luo Y, et al:: ABT-888, an orally active poly(ADP-ribose) polymerase inhibitor that potentiates DNA-damaging agents in preclinical tumor models. Clin Cancer Res. 2007; 13(9): 2728-37.

PubMed Abstract | Publisher Full Text

93. Topp MS, Gökbuget N, Zugmaier G, et al.: Phase II trial of the anti-CD19 bispecific $T$ cell-engager blinatumomab shows hematologic and molecular remissions in patients with relapsed or refractory B-precursor acute Iymphoblastic leukemia. J Clin Oncol. 2014; 32(36): 4134-40. PubMed Abstract | Publisher Full Text

94. Fuka G, Kantner HP, Grausenburger R, et al:: Silencing of ETV6/RUNX1 abrogates PI3K/AKT/mTOR signaling and impairs reconstitution of leukemia in xenografts. Leukemia. 2012; 26(5): 927-33. PubMed Abstract | Publisher Full Text

95. Diaz-Flores E, Comeaux EQ, Kim KL, et al.: Bcl-2 Is a Therapeutic Target for Hypodiploid B-Lineage Acute Lymphoblastic Leukemia. Cancer Res. 2019; 79(9): 2339-51.

PubMed Abstract | Publisher Full Text | Free Full Text |

Faculty Opinions Recommendation

96. Roberts KG, Li Y, Payne-Turner D, et al.: Targetable kinase-activating lesions in Ph-like acute lymphoblastic leukemia. N Engl J Med. 2014; 371(11): 1005-15. PubMed Abstract | Publisher Full Text | Free Full Text |

Faculty Opinions Recommendation

97. Sanchez PV, Perry RL, Sarry JE, et al.: A robust xenotransplantation model for acute myeloid leukemia. Leukemia. 2009; 23(11): 2109-17. PubMed Abstract | Publisher Full Text | Free Full Text

98. Bonnet $\mathrm{D}$ : Acute myeloid leukemia including favorable-risk group samples engraft in NSG mice: Just be patient. Haematologica. 2017; 102(5): 805-6. PubMed Abstract | Publisher Full Text | Free Full Text

99. Patient-Derived Xenograft Models of Human Cancer. (Springer International Publishing, 2017). Publisher Full Text

100. Feuring-Buske M, Gerhard B, Cashman J, et al.: Improved engraftment of human acute myeloid leukemia progenitor cells in beta 2-microglobulin-deficient NOD/SCID mice and in NOD/SCID mice transgenic for human growth factors. Leukemia. 2003; 17(4): 760-3.

PubMed Abstract | Publisher Full Text

101. Touzeau C, Dousset C, Le Gouill S, et al.: The Bcl-2 specific BH3 mimetic ABT199: a promising targeted therapy for $\mathrm{t}(11 ; 14)$ multiple myeloma. Leukemia. 2014; 28(1): 210-2. PubMed Abstract | Publisher Full Text | Free Full Text

102. Souers AJ, Leverson JD, Boghaert ER, et al.: ABT-199, a potent and selective BCL-2 inhibitor, achieves antitumor activity while sparing platelets. Nat Med. 2013; 19(2): 202-8.

PubMed Abstract | Publisher Full Text | Faculty Opinions Recommendation

103. Nowell $\mathrm{PC}$ : The minute chromosome $\left(\mathbf{P h}^{\prime}\right)$ in chronic granulocytic leukemia. Blut. 1962; 8: 65-6. PubMed Abstract | Publisher Full Text

104. Sawyers CL, Gishizky ML, Quan S, et al.: Propagation of human blastic myeloid leukemias in the SCID mouse. Blood. 1992; 79(8): 2089-98. PubMed Abstract | Publisher Full Text

105. Sirard C, Lapidot T, Vormoor J, et al: Normal and leukemic SCID-repopulating cells (SRC) coexist in the bone marrow and peripheral blood from CML patients in chronic phase, whereas leukemic SRC are detected in blast crisis. Blood. 1996; 87(4): 1539-48. PubMed Abstract | Publisher Full Text

106. Wang JC, Lapidot T, Cashman JD, et al.: High Level Engraftment of NOD/SCID Mice by Primitive Normal and Leukemic Hematopoietic Cells From Patients With Chronic Myeloid Leukemia in Chronic Phase. Blood. 1998; 91(7): 2406-14. PubMed Abstract | Publisher Full Text

107. Eisterer $\mathrm{W}$, Jiang $\mathrm{X}$, Christ $\mathrm{O}$, et al.: Different subsets of primary chronic myeloid leukemia stem cells engraft immunodeficient mice and produce a model of the human disease. Leukemia. 2005; 19(3): 435-41. PubMed Abstract | Publisher Full Text

108. Rizo A, Horton SJ, Olthof S, et al:: BMI1 collaborates with BCR-ABL in leukemic transformation of human CD34+ cells. Blood. 2010; 116(22): 4621-30. PubMed Abstract | Publisher Full Text

109. Schoepfer J, Jahnke W, Berellini G, et al.: Discovery of Asciminib (ABL001), 
an Allosteric Inhibitor of the Tyrosine Kinase Activity of BCR-ABL1. J Med Chem. 2018; 61(18): 8120-35.

PubMed Abstract | Publisher Full Text | Faculty Opinions Recommendation

110. W Wu J, Wang A, Li X, et al.: Discovery and characterization of a novel highly potent and selective type II native and drug-resistant V299L mutant BCR-ABL inhibitor (CHMFL-ABL-039) for Chronic Myeloid Leukemia (CML). Cancer Biol Ther. 2019; 20(6): 877-85.

PubMed Abstract | Publisher Full Text | Free Full Text |

Faculty Opinions Recommendation

111. Kapp U, Wolf $\mathrm{J}$, Hummel M, et al:: Hodgkin's lymphoma-derived tissue serially transplanted into severe combined immunodeficient mice. Blood. 1993; 82(4): 1247-56.

PubMed Abstract | Publisher Full Text

112. von Kalle $\mathrm{C}$, Wolf $\mathrm{J}$, Becker $\mathrm{A}$, et al.: Growth of Hodgkin cell lines in severely combined immunodeficient mice. Int J Cancer. 1992; 52(6): 887-91. PubMed Abstract | Publisher Full Text

113. M'kacher R, Frenzel M, Al Jawhari M, et al.: Establishment and Characterization of a Reliable Xenograft Model of Hodgkin Lymphoma Suitable for the Study of Tumor Origin and the Design of New Therapies. Cancers (Basel). 2018; 10(11): 414.

PubMed Abstract | Publisher Full Text | Free Full Text | Faculty Opinions Recommendation

114. Wahl AF, Klussman $\mathrm{K}$, Thompson JD, et al: The anti-CD30 monoclonal antibody SGN-30 promotes growth arrest and DNA fragmentation in vitro and affects antitumor activity in models of Hodgkin's disease. Cancer Res. 2002; 62(13): 3736-42.

PubMed Abstract

115. Borchmann $\mathrm{P}$, Treml JF, Hansen $\mathrm{H}$, et al: The human anti-CD30 antibody 5F11 shows in vitro and in vivo activity against malignant lymphoma. Blood. 2003; 102(10): 3737-42.

PubMed Abstract | Publisher Full Text

116. Böll $B$, Hansen $H$, Heuck $F$, et al:: The fully human anti-CD30 antibody $5 F 11$ activates NF-\{kappa\}B and sensitizes lymphoma cells to bortezomib-induced apoptosis. Blood. 2005; 106(5): 1839-42. PubMed Abstract | Publisher Full Text

117. Bartlett NL, Younes A, Carabasi MH, et al:: A phase 1 multidose study of SGN-30 immunotherapy in patients with refractory or recurrent $C D 30^{+}$hematologic malignancies. Blood. 2008; 111(4): 1848-54. PubMed Abstract | Publisher Full Text | Free Full Text

118. Francisco JA, Cerveny CG, Meyer DL, et al:: cAC10-vcMMAE, an anti-CD30monomethyl auristatin $\mathrm{E}$ conjugate with potent and selective antitumor activity. Blood. 2003; 102(4): 1458-65. PubMed Abstract | Publisher Full Text

119. Locatelli F, Mauz-Koerholz C, Neville K, et al:: Brentuximab vedotin for paediatric relapsed or refractory Hodgkin's lymphoma and anaplastic large-cell lymphoma: A multicentre, open-label, phase 1/2 study. Lancet Haematol. 2018; 5(10): e450-e461.

PubMed Abstract | Publisher Full Text | Faculty Opinions Recommendation

120. Daifu T, Umeda K, Kouzuki K, et al.: The NOD/Shi-scid/IL-2R $\gamma$ (null) mice xenograft model recapitulates anaplastic large cell lymphoma dissemination to the bladder. Leuk Lymphoma. 2015; 56(6): 1542-3. PubMed Abstract | Publisher Full Text

121. Awasthi A, Ayello J, van de Ven C, et al:: Polatuzumab Vedotin; Antibody Drug Conjugates (ADC, anti-CD79b-vc-MMAE, PV) Significantly Enhances in-Vitro Cell Death Against CD79b+ Burkitt Lymphoma (BL) /Primary Mediastinal Large B Cell Lymphoma (PMBL) and Improved Overall Survival Against Rituximab Sensitive/Resistant-BL NSG Xenograft Mice. Blood. 2016; 128(22): 4126. Publisher Full Text

122. Dalla-Favera R, Bregni M, Erikson J, et al:: Human c-myc onc gene is located on the region of chromosome $\mathbf{8}$ that is translocated in Burkitt lymphoma cells. Proc Natl Acad Sci U S A. 1982; 79(24): 7824-7. PubMed Abstract | Publisher Full Text | Free Full Text

123. Taub R, Kirsch I, Morton C, et al:: Translocation of the c-myc gene into the immunoglobulin heavy chain locus in human Burkitt lymphoma and murine plasmacytoma cells. Proc Natl Acad Sci U S A. 1982; 79(24): 7837-41. PubMed Abstract | Publisher Full Text | Free Full Text

124. Bishop PC, Rao VK, Wilson WH: Burkitt's lymphoma: Molecular pathogenesis and treatment. Cancer Invest. 2000; 18(6): 574-83. PubMed Abstract | Publisher Full Text

125. Abe M, Suzuki O, Tasaki K, et al.: Establishment and characterization of new human Burkitt's lymphoma cell lines (HBL-7 and HBL-8) that are highly metastatic in SCID mice: A metastatic SCID mouse model of human lymphoma lines. Pathol Int. 1996; 46(9): 630-8. PubMed Abstract | Publisher Full Text

126. Smith MR: Rituximab (monoclonal anti-CD20 antibody): Mechanisms of action and resistance. Oncogene. 2003; 22(47): 7359-68. PubMed Abstract | Publisher Full Text

127. Daudigeos-Dubus E, Le Dret L, Rouffiac V, et al.: Establishment and characterization of new orthotopic and metastatic neuroblastoma models. In Vivo. 2014; 28(4): 425-34. PubMed Abstract
128. Braekeveldt N, Bexell D: Patient-derived xenografts as preclinica neuroblastoma models. Cell Tissue Res. 2018; 372(2): 233-43. PubMed Abstract | Publisher Full Text | Free Full Text

129. Mujoo K, Kipps TJ, Yang HM, et al.: Functional properties and effect on growth suppression of human neuroblastoma tumors by isotype switch variants of monoclonal antiganglioside GD2 antibody 14.18. Cancer Res. 1989; 49(11): 2857-61. PubMed Abstract

130. Dhillon S: Dinutuximab: First global approval. Drugs. 2015; 75(8): 923-7. PubMed Abstract | Publisher Full Text

131. Barry WE, Jackson JR, Asuelime GE, et al.: Activated Natural Killer Cells in Combination with Anti-GD2 Antibody Dinutuximab Improve Survival of Mice after Surgical Resection of Primary Neuroblastoma. Clin Cancer Res. 2019; 25(1): 325-33. PubMed Abstract | Publisher Full Text | Free Full Text | Faculty Opinions Recommendation

132. Krytska K, Ryles HT, Sano R, et al.: Crizotinib Synergizes with Chemotherapy in Preclinical Models of Neuroblastoma. Clin Cancer Res. 2016; 22(4): 948-60. PubMed Abstract | Publisher Full Text | Free Full Text

133. Mossé YP, Laudenslager M, Longo L, et al.: Identification of $A L K$ as a majo familial neuroblastoma predisposition gene. Nature. 2008; 455(7215): 930-5. PubMed Abstract | Publisher Full Text | Free Full Text Faculty Opinions Recommendation

134. Wen JG, van Steenbrugge GJ, Egeler RM, et al:: Progress of fundamental research in Wilms' tumor. Urol Res. 1997; 25(4): 223-30. PubMed Abstract | Publisher Full Text

135. Mohseni MJ, Amanpour S, Muhammadnejad S, et al.: Establishment of a patientderived Wilms' tumor xenograft model: A promising tool for individualized cancer therapy. J Pediatr Urol. 2014; 10(1): 123-9. PubMed Abstract | Publisher Full Text

136. Murphy AJ, Chen X, Pinto EM, et al.: Forty-five patient-derived xenografts capture the clinical and biological heterogeneity of Wilms tumor. Nat Commun. 2019; 10(1): 5806

PubMed Abstract | Publisher Full Text | Free Full Text |

Faculty Opinions Recommendation

137. Stebbing J, Paz K, Schwartz GK, et al.: Patient-derived xenografts for individualized care in advanced sarcoma. Cancer. 2014; 120(13): 2006-15. PubMed Abstract | Publisher Full Text | Free Full Text

138. Grohar PJ, Glod J, Peer CJ, et al.: A phase I/II trial and pharmacokinetic study of mithramycin in children and adults with refractory Ewing sarcoma and EWS-FLI1 fusion transcript. Cancer Chemother Pharmacol. 2017; 80(3): 645-52. PubMed Abstract | Publisher Full Text | Free Full Text

139. Sterling-Levis $\mathrm{K}$, White $\mathrm{L}$ : The role of xenografting in pediatric brain tumor research with specific emphasis on medulloblastoma/primitive neuroectodermal tumors of childhood. In Vivo. 2003; 17(4): 329-42. PubMed Abstract

140. Mikami T, Kurisu K, Kawamoto $\mathrm{K}$, et al: Establishment and characterization of human medulloblastoma xenograft line. Hiroshima J Med Sci. 1991; 40(1): 41-5. PubMed Abstract

141. Tsangaris GT, Dimas K, Malamou A, et al.: Molecular Proteomic Characterization of a Pediatric Medulloblastoma Xenograft. Cancer Genomics Proteomics. 2017; 14(4): 267-75 PubMed Abstract | Publisher Full Text | Free Full Text

142. Anagnostopoulos AK, Papathanassiou C, Karamolegou K, et al.: Proteomic studies of pediatric medulloblastoma tumors with 17p deletion. J Proteome Res. 2015; 14(2): 1076-88. PubMed Abstract | Publisher Full Text

143. Joo KM, Kim J, Jin J, et al.: Patient-specific orthotopic glioblastoma xenograft models recapitulate the histopathology and biology of human glioblastomas in situ. Cell Rep. 2013; 3(1): 260-73.

PubMed Abstract | Publisher Full Text

144. Miyai M, Tomita $\mathrm{H}$, Soeda $\mathrm{A}$, et al.: Current trends in mouse models of glioblastoma. J Neurooncol. 2017; 135(3): 423-32. PubMed Abstract | Publisher Full Text | Free Full Text

145. Ricci-Vitiani $L$, Pallini $R$, Biffoni $M$, et al: Tumour vascularization via endothelial differentiation of glioblastoma stem-like cells. Nature. 2010; 468(7325): 824-8. PubMed Abstract | Publisher Full Text

146. Tateishi K, Wakimoto H, lafrate AJ, et al.: Extreme Vulnerability of IDH1 Mutant Cancers to NAD+ Depletion. Cancer Cell. 2015; 28(6): 773-84. PubMed Abstract | Publisher Full Text | Free Full Text | Faculty Opinions Recommendation

147. Ashizawa T, Miyata H, lizuka A, et al.: Effect of the STAT3 inhibitor STX-0119 on the proliferation of cancer stem-like cells derived from recurrent glioblastoma. Int J Oncol. 2013; 43(1): 219-27. PubMed Abstract | Publisher Full Text

148. Wykosky J, Hu J, Gomez GG, et al:: A urokinase receptor-Bim signaling axis emerges during EGFR inhibitor resistance in mutant EGFR glioblastoma. Cancer Res. 2015; 75(2): 394-404. PubMed Abstract | Publisher Full Text | Free Full Text Zeng J, See AP, Phallen J, et al.: Anti-PD-1 blockade and stereotactic 
radiation produce long-term survival in mice with intracranial gliomas. Int $J$ Radiat Oncol Biol Phys. 2013; 86(2): 343-9. PubMed Abstract | Publisher Full Text | Free Full Text | Faculty Opinions Recommendation

150. Parrish KE, Cen L, Murray J, et al.: Efficacy of PARP Inhibitor Rucaparib in Orthotopic Glioblastoma Xenografts Is Limited by Ineffective Drug Penetration into the Central Nervous System. Mol Cancer Ther. 2015; 14(12): 2735-43. PubMed Abstract | Publisher Full Text | Free Full Text

151. Gupta SK, Mladek AC, Carlson BL, et al.: Discordant in vitro and in vivo chemopotentiating effects of the PARP inhibitor veliparib in temozolomidesensitive versus -resistant glioblastoma multiforme xenografts. Clin Cancer Res. 2014; 20(14): 3730-41.

PubMed Abstract | Publisher Full Text | Free Full Text

152. Houghton $\mathrm{PJ}$, Morton $\mathrm{CL}$, Tucker $\mathrm{C}$, et al:: The pediatric preclinical testing program: description of models and early testing results. Pediatr Blood Cancer. 2007; 49(7): 928-40.

PubMed Abstract | Publisher Full Text

153. Kang MH, Smith MA, Morton CL, et al:: National Cancer Institute pediatric preclinical testing program: model description for in vitro cytotoxicity testing. Pediatr Blood Cancer. 2011; 56(2): 239-49. PubMed Abstract | Publisher Full Text | Free Full Text

154. Children Successfully MATCHed to Therapies. Cancer Discov. 2019; 9(7): OF3. PubMed Abstract | Publisher Full Text

155. Worst BC, van Tilburg CM, Balasubramanian GP, et al.: Next-generation personalised medicine for high-risk paediatric cancer patients - The INFORM pilot study. Eur J Cancer. 2016; 65: 91-101. PubMed Abstract | Publisher Full Text

156. Hernandez-llizaliturri FJ, Jupudy V, Ostberg J, et al: Neutrophils contribute to the biological antitumor activity of rituximab in a non-Hodgkin's lymphoma severe combined immunodeficiency mouse model. Clin Cancer Res. 2003; 9(16 Pt 1): 5866-73. PubMed Abstract

157. Siegler EL, Wang P: Preclinical Models in Chimeric Antigen ReceptorEngineered T-Cell Therapy. Hum Gene Ther. 2018; 29(5): 534-46. PubMed Abstract | Publisher Full Text

158. Spear $\mathrm{P}$, Barber $\mathrm{A}$, Rynda-Apple $\mathrm{A}$, et al:: Chimeric antigen receptor $\mathrm{T}$ cells shape myeloid cell function within the tumor microenvironment through IFN- $\gamma$ and
GM-CSF. J Immunol. 2012; 188(12): 6389-98. PubMed Abstract | Publisher Full Text | Free Full Text

159. $\mathrm{Jin} \mathrm{CH}, \mathrm{Xia} \mathrm{J}$, Rafiq S, et al.: Modeling anti-CD19 CAR T cell therapy in humanized mice with human immunity and autologous leukemia. EBioMedicine. 2019; 39: 173-81.

PubMed Abstract | Publisher Full Text | Free Full Text Faculty Opinions Recommendation

160. Pfeiffer A, Thalheimer FB, Hartmann S, et al:: In vivo generation of human CD19-CAR T cells results in B-cell depletion and signs of cytokine release syndrome. EMBO Mol Med. 2018; 10(11): e9158. PubMed Abstract | Publisher Full Text | Free Full Text | Faculty Opinions Recommendation

161. OXu X, Huang W, Heczey A, et al:: NKT Cells Coexpressing a GD2-Specific Chimeric Antigen Receptor and IL15 Show Enhanced In Vivo Persistence and Antitumor Activity against Neuroblastoma. Clin Cancer Res. 2019; 25(23): 7126-38.

PubMed Abstract | Publisher Full Text | Free Full Text |

Faculty Opinions Recommendation

162. Tian G, Courtney AN, Jena B, et al:: CD62L+ NKT cells have prolonged persistence and antitumor activity in vivo. J Clin Invest. 2016; 126(6): 2341-55. PubMed Abstract | Publisher Full Text | Free Full Text

163. Chen N, Morello A, Tano Z, et al:: CAR T-cell intrinsic PD-1 checkpoint blockade: A two-in-one approach for solid tumor immunotherapy. Oncoimmunology. 2017; 6(2): 11273302

PubMed Abstract | Publisher Full Text | Free Full Text

164. Scarfò I, Maus MV: Current approaches to increase CAR T cell potency in solid tumors: targeting the tumor microenvironment. J Immunother Cancer. 2017; 5: PubMed Abstract | Publisher Full Text | Free Full Text

165. Majzner RG, Theruvath JL, Nellan A, et al.: CAR T Cells Targeting B7-H3, a Pan-Cancer Antigen, Demonstrate Potent Preclinical Activity Against Pediatric Solid Tumors and Brain Tumors. Clin Cancer Res. 2019; 25(8): 2560-74. PubMed Abstract | Publisher Full Text | Faculty Opinions Recommendation

166. Yokota SJ, Facciponte JG, Kelleher RJ, et al.: Changes in ovarian tumor cell number, tumor vasculature, and $\mathrm{T}$ cell function monitored in vivo using a novel xenograft model. Cancer Immun. 2013; 13: 11. PubMed Abstract | Free Full Tex 